ABDI: Jurnal Pengabdian dan Pemberdayaan Masyarakat ISSN: 2656-369X (Print), 2684-8570 (Online)

Volume 3 No. 1, Juni 2021

http://abdi.ppj.unp.ac.id/index.php/abdi

Email: abdi@ppi.unp.ac.id

DOI: https://doi.org/10.24036/abdi.v3il.80

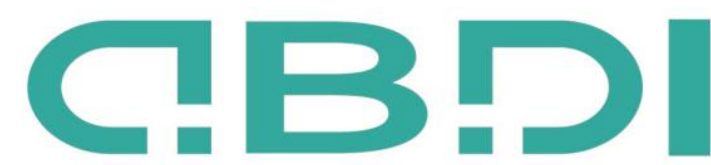

ABDI: JURNAL PENGABDIAN DAN PEMBERDAYAAN MASYARAKAT

\title{
Alat Pencuci Tangan Movable Jenis Touchless Sebagai Alat Pemutus Rantai Penularan Covid-19
}

\author{
Nasruddin Abdullah ${ }^{1}$, Zainal Arif ${ }^{2}$, Suheri Suheri ${ }^{3}$ \\ ${ }^{1,2,3}$ Program Studi Teknik Mesin / Universitas Samudra
}

Email: nasruddin@unsam.ac.id, zainalarif@unsam.ac.id, $\underline{\text { suheri@unsam.ac.id }}$

\begin{abstract}
Abstrak
Salah satu protokol World Health Organization (WHO) dalam memutus rantai penularan Coronavirus disease 2019 COVID-19 dengan prosedur mencuci tangan. Ketersediaan alat pencuci tangan dengan standar yang baik dan sesuai dengan standar WHO sangat dibutuhkan pada masa pandemi. Cara yang paling efektif untuk melakukan cuci tangan adalah dengan menggunakan sabun dan air mengalir. Di tempat umum sangat sulit untuk mendapatkan sabun dan air mengalir, jika pun ada, pengunaan kran manual dapat meningkatkan penularan Coronavirus disease 2019 COVID-19 karena sentuhan tangan seseorang pada kran atau tombol sabun akan meninggalkan virus tersebut dan dapat menyebarkan virus tersebut ke pengguna selanjutnya. Penggunaan Alat Pencuci Tangan Moveable Jenis Touchless dapat membantu mengurangi penyebaran Ketika proses pencuci tangan, karena tidak ada sentuhan sama sekali pada komponen-komponen pencuci tangan, Dengan menggunakan Alat Pencuci Tangan Moveable Jenis Touchless ini diharapkan dapat membantu masyarakat agar dapat mencuci tangan dengan standar yang tinggi dimana saja dan kapan saja, sehingga pada akhirnya dapat mengurangi penyebaran Virus COVID-19 di area umum. Dan diharapkan kebiasaan ini juga dapat dilanjutkan tidak hanya pada masa pandemi tetapi pada masa berlanjut setalah pandemi berakhir. Pemasangan alat akan dilakukan di tempat masyarakat umur berkumpul dan dapat dipindahkan dengan mudah.
\end{abstract}

Kata kunci: COVID-19, Moveable, Touchless

\section{Abstract}

One of the World Health Organization (WHO) protocols in breaking the chain of transmission of COVID-19 by washing hands. The availability of hand washing equipment with good standards and in accordance with WHO standards is urgently needed during a pandemic. The most effective way to wash your hands is by using soap and running water. In public places it is very difficult to get soap and running water, if any, using manual taps can increase transmission of Coronavirus disease 2019 (COVID-19) because touching someone's hand on a faucet or a soap button will leave the virus and can spread the virus to future users. Use of the Touchless Type of Handwashing Tool can help reduce the spread of the hand washing process, because there is no touch at all on the components of the hand washing, using the Touchless Type of Handwashing Tool is expected to help people wash their hands with high standards. anywhere and anytime, so that in the end it can reduce the spread of the COVID-19 Virus in public areas. And it is hoped that this habit can also be continued not only during the pandemic period but in the continuing period after the pandemic ends. The installation of the tools will be carried out in a place where the aged people gather and can be moved easily.

Key Word: COVID-19, Moveable, Touchless

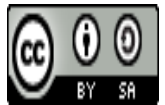

Received: 9 November $2020 \quad$ Revised: 26 Maret $2021 \quad$ Available Online: 29 Maret 2021 


\section{Pendahuluan}

Penyebaran Coronavirus disease 2019 (COVID-19) pada masa sekarang ini sedang meningkat penyebaran virus ini sangat sulit dikendalikan dan membutuhkan kedisiplinan dan usaha yang keras. COVID-19 dapat mengakibatkan infeksi jika virus tersebut masuk ke dalam tubuh manusia, infeksi ini diakibatkan oleh Severe Acute Respiratory Syndrome-related Coronavirus 2 (SARS-CoV-2).

Penyebaran virus corona ini dapat terjadi melalui droplet, yaitu suatu cairan yang keluar dari tubuh manusia Ketika bersin atau batuk. Dari data penelitian terkini, bahwa COVID-19 dapat menular dari manusia ke manusia (Wang, 2020) . Virus yang tertular dapat masuk ke dalam tubuh melalui indra yang ada di wajah seperti hidung, mata dan mulut, sehingga sangat rentan jika menyentuh wajah dengan tangan yang telah tertular virus. Penularan virus kepada diri sendiri dan orang lain dapat dicegah dengan mencuci tangan pakai sabun dan air yang mengalir secara benar (Huang \& Stack, 2012). Cuci tangan secara rutin merupakan salah satu metode yang sangat penting dalam penyebaran virus.

Penggunaan hand sanitizer merupakan salah satu cara untuk mencegah penyebaran virus, namun masih memiliki banyak kelemahan diantaranya: tingkat ketersediaan yang rendah Ketika terjadi pandemi, juga tingkat efektivitas yang rendah, ketika digunakan pada tangan dalam kondisi kotor dan droplet yang belum kering (Hirose, 2019). COVID-19 ini mempunyai bentuk yang sangat kecil dan tidak terlihat dengan mata telanjang, sehingga sangat sulit mendeteksi keberadaannya (Elston, 2020). Frekuensi cuci tangan merupakan salah satu faktor untuk mengurangi risiko yang penting dalam menjaga kondisi selama pandemi COVID-19 mengingat kemampuan bertahan hidup virus ini cukup lama pada permukaan kulit maupun benda-benda yang ada di sekitar kita. Fasilitas cuci tangan di tempat umum merupakan salah satu cara yang dapat menurunkan penyebaran virus yang disebabkan oleh kontak tangan, karena kontak tangan pada permukaan benda-benda di tempat umum sangat sulit dihindari (World Health Organization, 2020a). Tingkat penyebaran dan kemungkinan tertular COVID-19 ini di tempat umum sangat tinggi, seperti di pasar, rumah sakit.

Pada Desember 2019, kasus pneumonia misterius pertama kali dilaporkan di Wuhan, Provinsi Hubei. Sumber penularan kasus ini masih belum diketahui pasti, tetapi kasus pertama dikaitkan dengan pasar ikan di Wuhan. Tanggal 18 Desember hingga 29 Desember 2019, terdapat lima pasien yang dirawat dengan Acute Respiratory Distress Syndrome (ARDS) (World Health Organization, 2020b). Sejak 31 Desember 2019 hingga 3 Januari 2020 kasus ini meningkat pesat, ditandai dengan dilaporkannya sebanyak 44 kasus. Tidak sampai satu bulan, penyakit ini telah menyebar di berbagai provinsi lain di China, Thailand, Jepang, dan Korea Selatan. Sampel yang diteliti menunjukkan etiologi coronavirus baru (World Health Organization, 2020c). Awalnya, penyakit ini dinamakan sementara sebagai 2019 novel coronavirus (2019-nCoV), kemudian WHO mengumumkan nama baru pada 11 Februari 2020 yaitu Coronavirus Disease (COVID-19) yang disebabkan oleh virus Severe Acute Respiratory Syndrome Coronavirus-2 (SARS-CoV-2) (Huang et al., 2020). Virus ini dapat ditularkan dari manusia ke manusia dan telah menyebar secara luas di China dan lebih dari 190 negara dan teritori lainnya (Wu \& McGoogan, 2020). Pada 12 Maret 2020, WHO mengumumkan COVID-19 sebagai pandemik. [11] Hingga tanggal 29 Maret 2020, terdapat 634.835 kasus dan 33.106 jumlah kematian di seluruh dunia (Kementerian Kesehatan Republik Indonesia, 2020). Sementara di Indonesia sudah ditetapkan 1.528 kasus dengan positif COVID-19 dan 136 kasus kematian COVID19 pertama dilaporkan di Indonesia pada tanggal 2 Maret 2020 sejumlah 2 (dua) kasus (World Health Organization, 2020d). Data 31 Maret 2020 menunjukkan kasus yang terkonfirmasi berjumlah 1.528 kasus dan 136 kasus kematian (World Health Organization, 2009). Tingkat mortalitas COVID-19 di Indonesia sebesar 8,9\%, angka ini merupakan yang tertinggi di Asia Tenggara.

\section{Metode Pelaksanaan}

Kegiatan Pengabdian Kepada Masyarakat yang dilakukan oleh Tim pengabdi dari Dosen Teknik Mesin Universitas Samudra kepada mitra yang berada di Desa Tualang Cut Kabupaten Aceh Tamiang dibawah pengawasan Lembaga Penelitian Pengabdian Masyarakat dan Penjamin Mutu (LPPM-PM) Universitas Samudra yang dilaksanakan selama empat bulan terhitung mulai bulan Juli 
sampai dengan Oktober 2020. Pelaksanaan kegiatan ini dibagi dalam beberapa tahapan yaitu, survey lapangan, studi literature, pertemuan dengan para perangkat desa, pembuatan alat cuci tangan dan penyerahan ke lokasi. Proses dalam membuat alat cuci tangan tanpa sentuh, menggunakan suatu alat kontrol yang diprogram menggunakan sensor ultrasonik. Penggunaan sensor ini dengan pertimbangan tingkat akurasinya yang cukup tinggi. Alat sensor ini bekerja dengan memancarkan gelombang sonik ke area di sekitarnya, gelombang tersebut akan memantul jika mengenai suatu benda. Pantulan gelombang yang dipancarkan akan dapat diperhitungkan berapa jarak antara pemancar dengan objek. Ketika tangan didekatkan ke Keran, maka sinyal akan dikirimkan ke alat sensor untuk membuka keran yang telah dilengkapi dengan motor servo, sehingga kran dapat terbuka dan mengalirkan air, jumlah air yang dialirkan dibatasi sesuai waktu yang diberikan pada controller. Program ini diatur oleh suatu micro controller yang dapat menerima sinyal dan memberi perintah pada sistem control ditunjukkan pada Gambar 1. Begitu juga dengan pengaturan pengunaan sabun cuci tangan dikontrol oleh mikro prosesor dengan sinyal ultrasonik. Penggunaan sistem ini selain dapat mencegah terjadinya kontak permukaan antara masyarakat yang sedang beraktivitas.

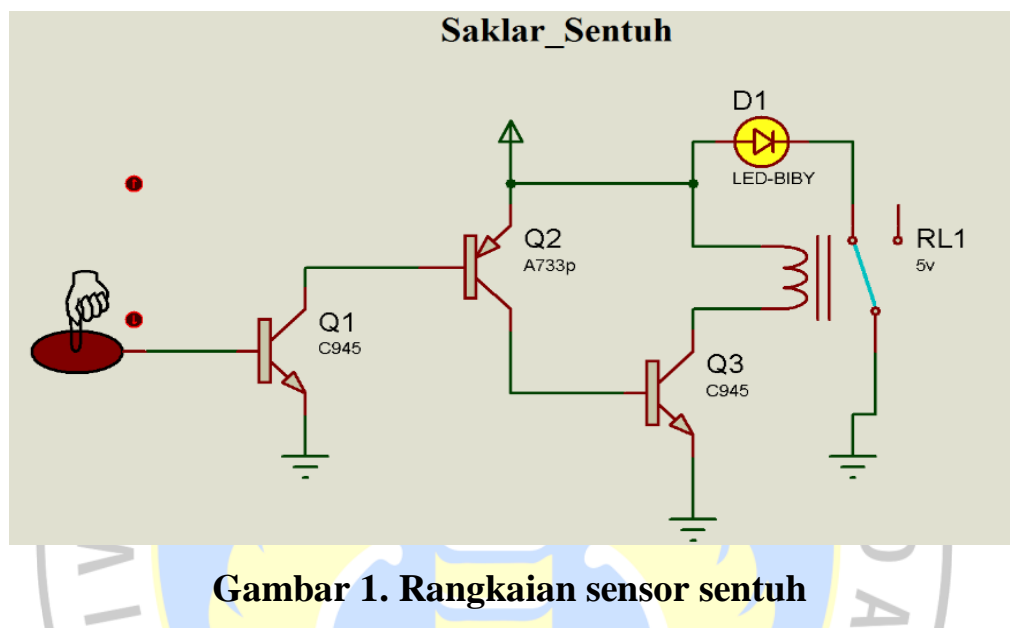

Spesifikasi alat yang ditawarkan ini adalah jenis movable, portable dan touchless, artinya jenis alat yang mudah dipindahkan dan dibawa-bawa sesuai dengan kondisi dimana area yang lebih tepat digunakan dan di area yang sedang membutuhkan dengan operasional tanpa sentuh. Selain itu alat ini memenuhi persyaratan sesuai dengan persyaratan yang telah disampaikan pada bagian target dan luaran. Informasi pengunaan dan poster tentang informasi yang berhubungan dengan COVID-19 dan cuci tangan di pasang di area tempat alat cuci tangan itu diletakkan.

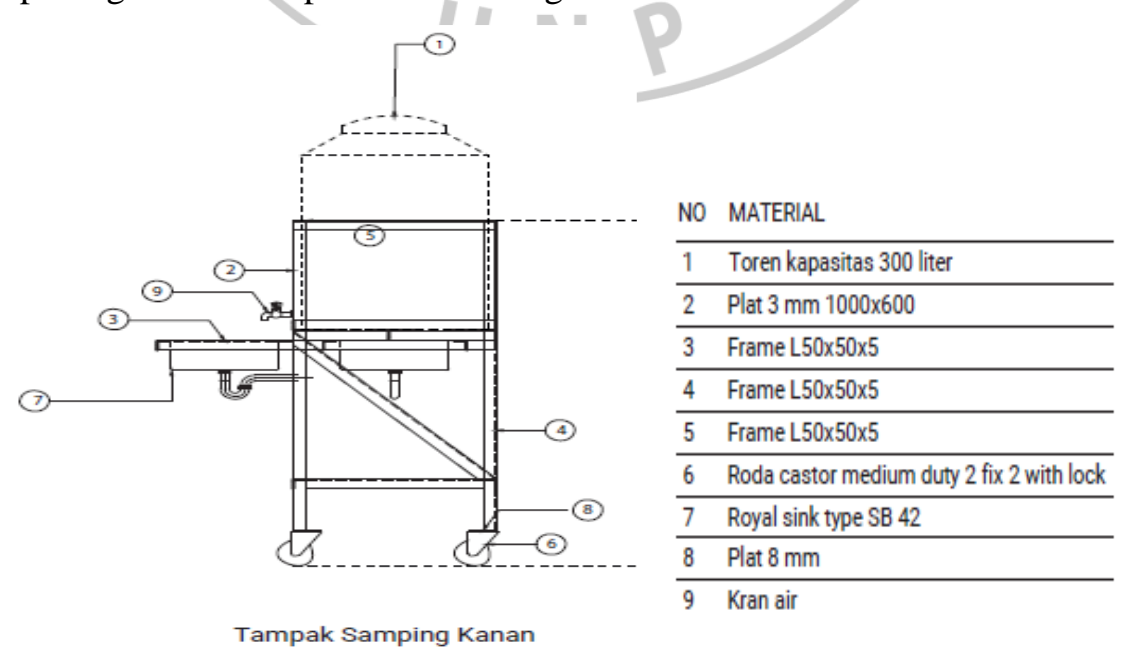

Gambar 2. Desain alat cuci tangan 
Sosialisasi pengunaan, operasional serta pemeliharaan dilakukan dengan perangkat desa melalui pengurus pasar, sehingga alat cuci tangan bisa sustainable dan bermanfaat. Dilakukan koordinasi langsung dengan perangkat desa dan pengurus pasar selama proses pemasangan dan pemasangan, sehingga program cuci tangan ini dapat tersosialisasi dengan baik. Penggunaan barang habis pakai untuk pertama akan disediakan, namun untuk pemakaian selanjutnya akan disediakan oleh desa dan pengurus pasar, selanjutnya untuk pemeliharaan juga akan dilakukan oleh perangkat desa dan pengurus pasar.

\section{Hasil dan Pembahasan}

Kegiatan Pengabdian Kepada Masyarakat dengan judul "alat pencuci tangan moveable jenis touchless sebagai alat pemutus rantai penularan covid-19 di pasar Tualang Baru" dilaksanakan pada bulan Juli hingga Oktober 2020. Hasil kegiatan pengabdian kepada masyarakat yang telah dilaksanakan di pasar Tualang baru, kabupaten Aceh Tamiang mendapat respon yang positif dari berbagai elemen masyarakat khususnya masyarakat sekitar pasar Tualang Baru yang sangat memerlukan penanganan dan pencegahan Covid-19 dan menjadi tempat titik kumpul pada setiap minggu. Para perangkat desa juga sangat terbantu dalam pencegahan penyebaran virus Covid-19 yang ada di wilayah Tualang Baru.

Kegiatan ini merupakan bagian peningkatan wawasan dosen dan perwujudan yang ke 3 (tiga) Tri Dharma Perguruan Tinggi yaitu pengabdian kepada masyarakat sebagai kontribusi sumbangan pemikiran dosen kepada masyarakat umum. Berikut dokumentasi hasil kegiatan pengabdian kepada masyarakat (PKM) dengan judul "alat pencuci tangan moveable jenis touchless sebagai alat pemutus rantai penularan covid-19 di pasar Tualang Baru" yang dilaksanakan di Desa Tualang baru kabupaten Aceh Tamiang.

Penularan virus akan semakin cepat disebabkan kurangnya kepedulian terhadap kebersihan baik individu maupun kelompok. Alat ini diharapkan mampu mencegah penyebaran virus di Pasar Desa Tualang Cut, seluruh masyarakat juga turut mendukung dan menggunakan alat ini dengan baik. Kegiatan yang dilakukan memberikan kesan antusias yang begitu besar dari pemerintah daerah melalui kepala desa. Hal ini dibuktikan dengan adanya dukungan penuh setiap aktifitas selama kegiatan pengabdian. Pihak kampus juga mengajak untuk selalu bersinergi dalam pencegahan penularan virus di daerah Tualang Cut.

Pengabdian kepada masyarakat yang telah dilakukan dapat meningkatkan ilmu pengetahuan dalam bidang teknik mesin sehingga mahasiswa yang terlibat dalam kegiatan ini. Mereka dapat melanjutkan dan mengembangkan jenis alat cuci tangan yang sesuai dengan kondisi terkini. Pada saat ini perkembangan alat cuci tangan sangat diperlukan ditengah masa pandemi seperti ini, alat cuci tangan pada umumnya harus dilakukan dengan manual dan kurang efektif, sedangkan alat cuci tangan dengan menggunakan sensor sangat efektif.
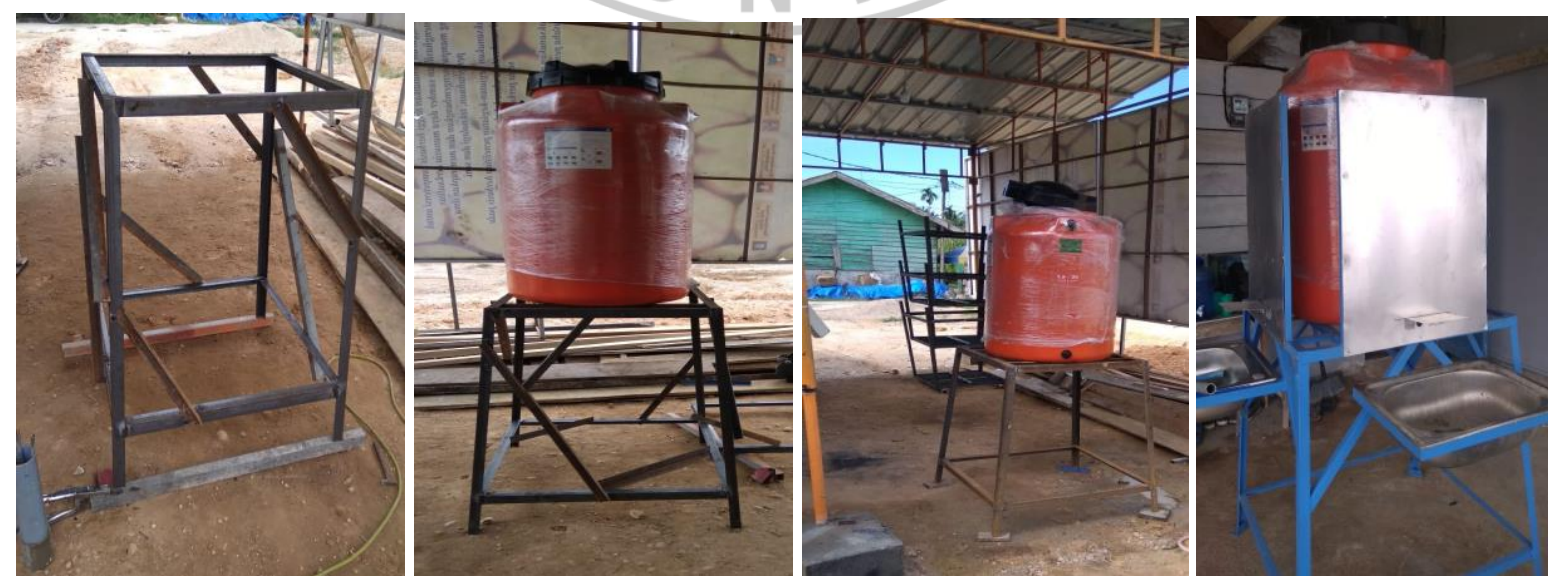

Gambar 3. Proses pembuatan alat cuci tangan 
Alat cuci tangan dapat menjadi salah satu cara untuk mencegah penularan virus Covid-19, secara rutin mencuci tangan dengan pakai sabun dan menjaga pola hidup bersih dan sehat dapat terjaga dari virus yang sedang berkembang. Target luaran dari kegiatan ini adalah meningkatkan pengetahuan masyarakat tentang bahaya covid-19 dan upaya pencegahan yang dapat dilakukan, serta pemberian masker kepada masyarakat dengan harapan dapat meningkatkan kesadaran masyarakat dalam menggunakan masker jika akan keluar rumah sebagai salah satu langkah meminimalisir penularan covid-19.

Dalam rangka penyempurnaan kegiatan pengabdian masyarakat, maka tim mengusulkan kegiatan di masa yang akan datang yaitu kegiatan edukasi kesehatan lainnya terkait pencegahan covid-19 ini seperti edukasi mengenai cara mencuci masker kain, aktivitas fisik yang dapat dilakukan dirumah selama wabah, pengolahan makanan bergizi selama wabah. Edukasi dapat dilaksanakan melalui media lain yang lebih inovatif. Hal ini bertujuan untuk menambah pengetahuan dan wawasan masyarakat terkait pencegahan penularan covid-19.

\section{Kesimpulan}
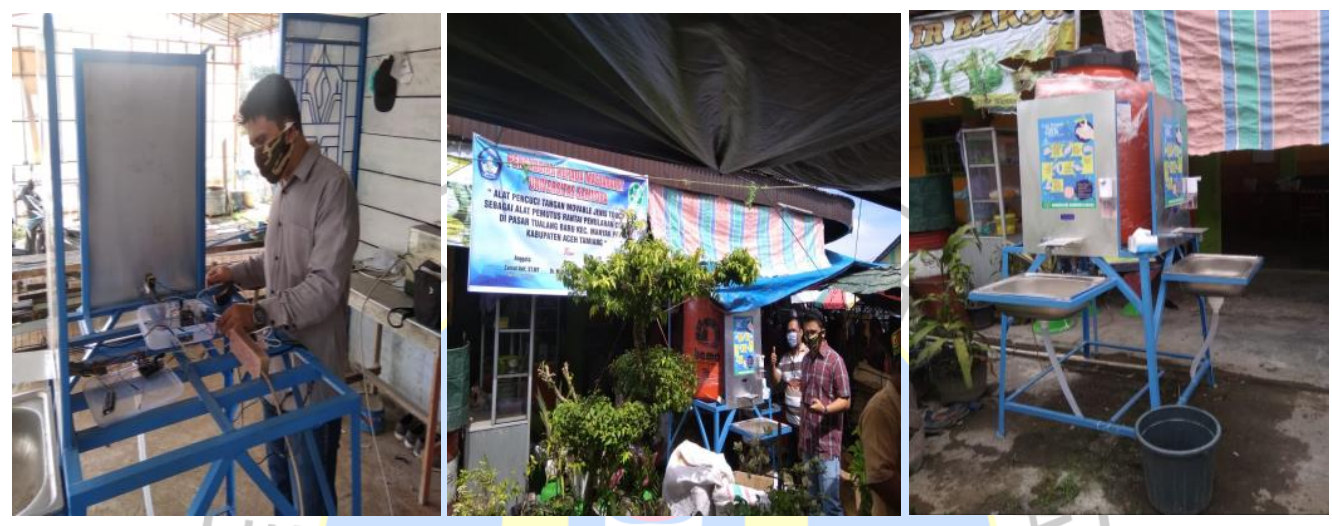

Gambar 4. Hasil alat cuci tangan

Berdasarkan hasil monitoring dan evaluasi yang telah dilakukan, maka dapat disimpulkan bahwa: (1) Adanya kesadaran masyarakat untuk mencuci tangan sebagai bentuk penanggulangan penyebaran virus Covid-19, (2) Memberikan contoh perilaku hidup sehat di lingkungan sekitar, (3) Adanya keinginan masyarakat untuk selalu mencuci tangan setelah melakukan kegiatan di pasar, (4) Dengan adanya alat cuci tangan otomatis ini sangat memudahkan masyarakat untuk melakukan cuci tangan dengan benar dan mudah serta dapat memutus rantai penyebaran virus Covid-19 di alat dan di lingkungan sekitarnya. (5) Perlu tambahan dana untuk menambah alat cuci tangan untuk menjangkau pusat-pusat keramaian (seperti, masjid, kantor desa, sekolah, bank), (6) Perlu adanya pendampingan kepada seluruh elemen masyarakat untuk bersama-sama dalam menghadapi kondisi new normal dengan tetap mematuhi protokol kesehatan. (7) Dukungan dan kolaborasi semua pihak sangat diperlukan pada saat melewati wabah pandemi Covid-19.

\section{Daftar Pustaka}

Elston, D. M. (2020). Occupational skin disease among health care workers during the coronavirus (COVID-19) epidemic. Journal of the American Academy of Dermatology, 82(5), 1085.

Hirose, R. (2019). Situations leading to reduced effectiveness of current hand hygiene against infectious mucus from influenza virus-infected patients. MSphere, 4(5), 19.

Huang, C., \& Stack, S. (2012). The hygienic efficacy of different hand-drying methods: a review of the evidence. Mayo Clinic Proceedings.

Huang, C., Wang, Y., Li, X., Ren, L., Zhao, J., \& Hu, Y. (2020). Clinical features of patients infected with 2019 novel coronavirus in Wuhan, China. Lancet, 395(10223), 497-506. 
Kementerian Kesehatan Republik Indonesia. (2020). Info Infeksi Emerging Kementerian Kesehatan RI. Retrieved from Kementerian Kesehatan Republik Indonesia website: https://infeksiemerging.kemkes.go.id/.

Wang, C. (2020). A novel coronavirus outbreak of global health concern. The LAncet, 395(10223), $470-473$.

World Health Organization. (2009). Hand Hygiene: Why, How \& When? Retrieved from World Health Organization website: https://www.who.int/gpsc/5may/Hand_Hygiene_Why_ How_and_When_Brochure.pdf

World Health Organization. (2020a). Naming the coronavirus disease (COVID-19) and the virus that causes it. Retrieved from World Health Organization website: https://www.who.int/ emergencies/diseases/novel-coronavirus-2019/technical-guidance/naming-the-coronavirusdisease-(covid-2019)-and-the-virus-that-causes-it.

World Health Organization. (2020b). Situation Report - 10. Retrieved from World Health Organization website: https://www.who.int/docs/default-source/coronaviruse/situationreports/20200130-sitrep-10-

World Health Organization. (2020c). Situation Report - 42. Retrieved from World Health Organization website: https://www.who.int/docs/default-source/coronaviruse/situationreports/20200302-sitrep-42-covid-19.pdf?sfvrsn=224c1add_2.

World Health Organization. (2020d). WHO Director-General's opening remarks at the media briefing on COVID-19. Retrieved from World Health Organization website: https://www.who.int/dg/speeches/detail/who-director-general- s-opening-remarks-at-the-mediabriefing-on-covid-19--11- march-2020.

Wu, Z., \& McGoogan, J. (2020). Characteristics of and Important Lessons From the Coronavirus Disease 2019 (COVID-19) Outbreak in China: Summary of a Report of 72314 Cases From the Chinese Center for Disease Control and Prevention. JAMA, 1(1), 2648.

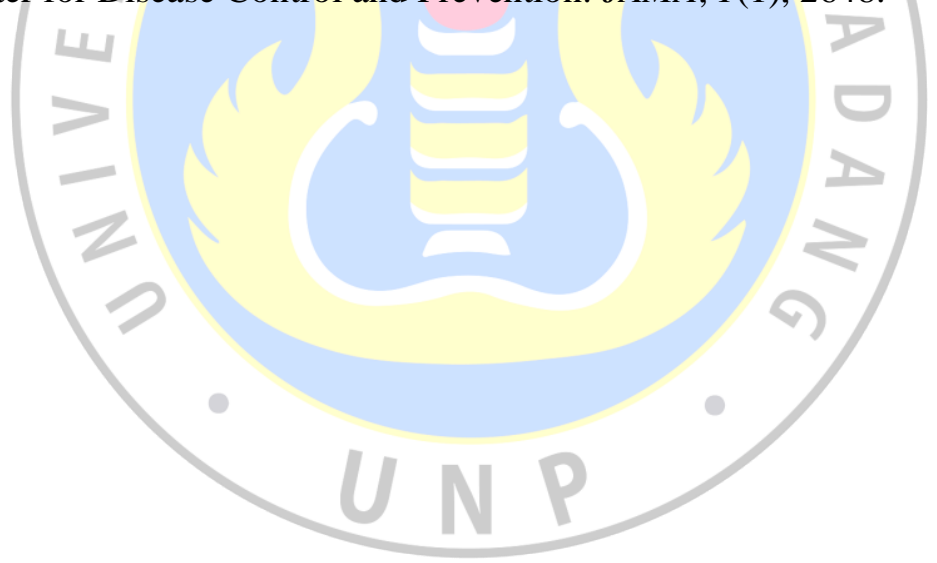

